\title{
Genetic and Phenotypic Diversity of Sclerotium rolfsii in Groundnut Fields in Central Vietnam
}

C. N. Le, Laboratory of Phytopathology, Wageningen University, The Netherlands, and Department of Plant Protection, Hue University of Agriculture and Forestry (HUAF), Vietnam; and R. Mendes, M. Kruijt, and J. M. Raaijmakers, Laboratory of Phytopathology, Wageningen University

\begin{abstract}
Le, C. N., Mendes, R., Kruijt, M., and Raaijmakers, J. M. 2012. Genetic and phenotypic diversity of Sclerotium rolfsii in groundnut fields in central Vietnam. Plant Dis. 96:389-397.

Groundnut (Arachis hypogaea) is an economically important legume crop in Vietnam and many other countries worldwide. Stem and pod rot, caused by the soilborne fungus Sclerotium rolfsii, is a major yieldlimiting factor in groundnut cultivation. To develop sustainable measures to control this disease, fundamental knowledge of the epidemiology and diversity of $S$. rolfsii populations is essential. In this study, disease incidence was monitored in eight groundnut areas in central Vietnam with a total of 240 observational field plots. The results showed that 5 to $25 \%$ of the field-grown groundnut plants were in-

fected by $S$. rolfsii. Based on internal transcribed spacer (ITS) ribosomal DNA sequence analyses, three distinct groups were identified among a total of 103 randomly selected $S$. rolfsii field isolates, with the majority of the isolates $(n=90)$ in one ITS group. $S$. rolfsii isolates originating from groundnut, tomato, and taro were all pathogenic on groundnut and relatively sensitive to the fungicide tebuconazole but displayed substantial diversity of various genetic and phenotypic traits, including mycelial compatibility, growth rate, and sclerotial characteristics.
\end{abstract}

Groundnut (Arachis hypogaea L.) is an annual legume crop cultivated in more than 80 countries in the tropics, subtropics, and warm temperate zones (15). It is a major source of edible oil, vitamins, and amino acids and is used extensively for feed and food (36). In terms of economic importance, it ranks 13th among the world food crops and tops the list of oil seed crops both in terms of acreage and production. In 2009, groundnut was grown on 23.5 million ha worldwide, with an estimated total production of 35.5 million tons (13). In Vietnam, groundnut is the most important oil crop, with a total area of 256,000 ha and a production of 534,000 tons in 2008 (13).

Groundnut cultivation is adversely affected by a wide range of pests and diseases, including subterranean pests and foliage feeders (11), leaf spots, rust, stem rot, seedling diseases, limb and pod rot, nematodes, and viral diseases (38). In Vietnam, black collar rot caused by Aspergillus niger Tiegh., damping-off caused by Rhizoctonia solani Kühn, and stem and pod rot caused by Sclerotium rolfsii Sacc. (teleomorph: Athelia rolfsii (Curzi) C.C. Tu \& Kimbr.) are the most important soilborne fungal diseases of groundnut $(20,23)$. $S$. rolfsii overwinters as mycelium or sclerotia in infected plant tissues and soil. Under favorable conditions, hyphae or germinating sclerotia infect the plant and subsequently colonize and invade the root and stem tissue with typical silkywhite mycelium (10). Infected plants become yellow and then wilt, and the collar root turns brown and rots; in addition, $S$.

Corresponding author: J. M. Raaijmakers, E-mail: jos.raaijmakers@wur.nl

Present address of R. Mendes: Laboratory of Environmental Microbiology, Embrapa, Jaguariuna, Brazil.

Present address of M. Kruijt: Monsanto Holland, Bergschenhoek, The Netherlands.

* The $\boldsymbol{e}$-Xtra logo stands for "electronic extra" and indicates that Figures 1, 2,3 , and 5 appear in color in the online edition.

Accepted for publication 13 October 2011.

http://dx.doi.org/10.1094/PDIS-06-11-0468

(c) 2012 The American Phytopathological Society rolfsii infects the groundnut pegs and pods, leading to yield losses.

S. rolfsii is difficult to control by physical and cultural practices due to its wide host range of over 500 plant species $(3,28)$ and persistent sclerotia $(19,28)$. Currently, there are only a few resistant cultivars commercially available $(6,7,43)$. In Vietnam, methods to control $S$. rolfsii include rotation with non-host crops or deep coverage of infected crop debris with soil during land preparation. However, these methods are laborious and not effective due to the broad host range and persistence of $S$. rolfsii. Fungicides frequently used to control $S$. rolfsii include pentachloronitrobenzene, flutolanil (37), and tebuconazole $(4,5,9)$. All three fungicides are effective in many cases, although tolerance to these fungicides was reported for $S$. rolfsii populations from groundnut fields in the United States $(14,39,41)$. In Vietnam, these fungicides are not yet used on a regular basis and large scale due to their relatively high costs for subsistence farmers.

To successfully implement management practices (e.g., chemical and biological) to control $S$. rolfsii, knowledge of the distribution and diversity of the pathogen is essential. The diversity of $S$. rolfsii has been assessed for field populations in Georgia, United States (14) and Ibaraki, Japan (25) but, for most other groundnut-producing countries, including Vietnam, the information on the distribution, severity and diversity is scarce or not available. Here, we monitored the incidence of Sclerotium stem rot of groundnut in fields in central Vietnam and characterized $S$. rolfsii populations genetically and phenotypically. The implications of our findings for developing sustainable and appropriate strategies to control stem and pod rot in Vietnam are discussed.

\section{Materials and Methods}

Disease incidence, $S$. rolfsii isolation, and preservation. In 2009, the disease incidence of stem and pod rot was monitored in groundnut fields in four provinces in central Vietnam (i.e., Quang Nam, Thua Thien Hue, Ha Tinh, and Nghe An; Fig. 1). In each province, samples were obtained from groundnut plants grown at two locations at least $20 \mathrm{~km}$ apart, one with sandy soil and the other with clay loam soil. The disease incidence was assessed at flowering, the developmental stage at which groundnut is infected by $S$. rolfsii $(20,23)$ For all eight locations, disease incidence was determined in at least 10 farmer fields for a total of 30 randomly 
selected plots of $1 \mathrm{~m}^{2}$. Therefore, in total, 240 groundnut plots of 1 $\mathrm{m}^{2}$ (i.e., eight locations $\times 30$ plots) were monitored in central Vietnam to determine the disease incidence of stem and pod rot caused by $S$. rolfsii. From each of the eight locations, 50 samples of diseased tissue or sclerotia were collected, stored in plastic bags, and brought to the laboratory for $S$. rolfsii isolation. Samples were collected mainly from groundnut; however, diseased tissues from two other host crops (i.e., tomato [Solanum lycopersicum] and taro [Colocasia esculenta]) grown in the same fields were also collected and included for pathogen isolation. Besides sampling the eight locations, groundnut plants from a remote upland location $(100 \mathrm{~m}$ above sea level) in Nghe An province were also sampled (Fig. 1).

Sclerotium rolfsii was isolated and maintained according to the methods of Punja and Rahe (31). Diseased tissues and sclerotia



Fig. 1. Map of Vietnam showing the provinces where the incidence of stem rot of groundnut was monitored in 2009 and where Sclerotium rolfsii isolates were collected. The four provinces surveyed are A, Nghe An $\left(18^{\circ} 46^{\prime} \mathrm{N} 105^{\circ} 38^{\prime} \mathrm{E}\right)$; B, Ha Tinh $\left(18^{\circ} 21^{\prime} \mathrm{N} 105^{\circ} 51^{\prime} \mathrm{E}\right)$; C, Thua Thien Hue $\left(16^{\circ} 33^{\prime} \mathrm{N} 107^{\circ} 31^{\prime} \mathrm{E}\right)$; and D, Quang Nam $\left(15^{\circ} 47^{\prime} \mathrm{N}\right.$ $\left.108^{\circ} 21^{\prime} \mathrm{E}\right)$. Three more isolates of $\mathrm{S}$. rolfsii were collected from groundnut grown in the remote upland area of Nghe An province $(\varphi)$. For each of the four provinces, stem rot incidence was determined for groundnut plants grown in two soil types (clay loam and sandy soils). For each soil type and each province, the disease was recorded in 30 field plots of $1 \mathrm{~m}^{2}$. In the graphs on the right, the average disease incidence is presented and the standard error of the mean is indicated. An asterisk indicates a statistically significant difference $(P<0.05)$ between the disease incidence in sandy soil and that in clay loam soil.

Table 1. Internal transcribed spacer ribosomal DNA sequences of reference strains of Sclerotium rolfsii, S. delphinii, and S. coffeicola used in the phylogenetic analyses

\begin{tabular}{|c|c|c|c|c|c|}
\hline Accession number & Host & Origin & Year of isolation & Name & Reference \\
\hline GQ358518 & Ascocentrum and Ascocenda spp. & South Florida, United States & 2008 & S. rolfsii & 12 \\
\hline DQ484060 & Unknown & Unknown & Unknown & S. rolfsii & 21 \\
\hline DQ484061 & Unknown & Unknown & Unknown & S. rolfsii & 21 \\
\hline DQ484062 & Unknown & Unknown & Unknown & S. rolfsii & 21 \\
\hline AB 075307 & Arachis hypogaea & Georgia, United States & 1991 & S. rolfsii & 26 \\
\hline GU080230 & Capsicum annuum & Spain & 2009 & S. rolfsii & 34 \\
\hline DQ059578 & Nicotiana tabacum & North Carolina, United States & 2007 & S. rolfsii & 35 \\
\hline AB 075318 & Unknown & Washington, United States & 1991 & S. delphinii & 26 \\
\hline $\mathrm{AB} 075314$ & Unknown & Japan & 1995 & S. delphinii & 26 \\
\hline AB075312 & Unknown & Japan & 1992 & S. delphinii & 26 \\
\hline AB075319 & Unknown & Surinam & 1919 & S. coffeicola & 26 \\
\hline
\end{tabular}


were surface sterilized for $2 \mathrm{~min}$ in $75 \%$ (vol/vol) ethanol, transferred to wet filter paper in petri plates, and incubated at $28^{\circ} \mathrm{C}$ for 2 to 3 days. Outgrowing mycelium was transferred to water agar medium and incubated for 2 days. From each sample, one or two hyphal tips were transferred to potato dextrose agar (PDA) plates to purify the fungal isolates. $S$. rolfsii isolates were kept on PDA slants in duplicate; one sample was covered with mineral oil for long term storage at $20^{\circ} \mathrm{C}$. From a total of more than 400 collected samples, $198 \mathrm{~S}$. rolfsii isolates were successfully purified, preserved, and subjected to internal transcribed spacer (ITS) ribosomal DNA (rDNA) sequencing.

ITS-rDNA amplification, sequencing, and phylogeny. Total DNA of $S$. rolfsii isolates was extracted based on the method of Tendulkar et al. (40). Each $S$. rolfsii isolate was cultured on PDA for $48 \mathrm{~h}$ at $25^{\circ} \mathrm{C}$, and then approximately $5 \mathrm{mg}$ (fresh weight) of mycelium was transferred to a $1.5-\mathrm{ml}$ tube. Tris-EDTA buffer (50 $\mu \mathrm{l}$ of $10 \mathrm{mM}$ Tris/ $\mathrm{HCl}$ and $1 \mathrm{mM}$ EDTA buffer, $\mathrm{pH} \mathrm{8)}$ was added and the sample was kept at room temperature (approximately $20^{\circ} \mathrm{C}$ ) for $10 \mathrm{~min}$, microwaved for $30 \mathrm{~s}$ at $650 \mathrm{~W}$, and centrifuged at a speed of $10,000 \mathrm{rpm}$ for $10 \mathrm{~min}$. The supernatant containing genomic DNA was used directly for ITS-rDNA amplification. Genomic DNA template $(4 \mu \mathrm{l})$ was used in a total reaction mixture volume of $50 \mu \mathrm{l}$. The mix contained $2.0 \mu \mathrm{l}$ of each of the four dNTPs ( $5 \mathrm{mM}$ stock each), $5.0 \mu \mathrm{l}$ of $10 \times$ polymerase chain reaction (PCR) buffer; $0.2 \mu \mathrm{l}$ of SuperTaq ( $5 \mathrm{U} / \mu \mathrm{l}$; SphaeroQ); $2 \mu \mathrm{l}$ of primers ITS1 and ITS4 (10 mM stock each) (42), and sterile MQ water. The PCR reaction involved 1 cycle at $94^{\circ} \mathrm{C}$ for $5 \mathrm{~min}$, and 35 repetitive cycles with $1 \mathrm{~min}$ at $94^{\circ} \mathrm{C}, 1 \mathrm{~min}$ at $55^{\circ} \mathrm{C}$, and $2 \mathrm{~min}$ at $72^{\circ} \mathrm{C}$. The PCR product $(2 \mu \mathrm{l})$ was loaded on a $1.5 \%(\mathrm{wt} / \mathrm{vol})$ agarose gel to assess the expected size (approximately $700 \mathrm{bp}$ ) and quantity of the PCR product. ITS-rDNA fragments were purified and sent for sequencing (Macrogen). The obtained forward and reverse sequences were assembled and edited in Vector NTI and deposited in GenBank with accession numbers HQ895865 to HQ895967. For the phylogenetic analyses, the edited sequences were trimmed (approximately $550 \mathrm{bp}$ ) and aligned to reference sequences available in databases (Table 1); the phylogenetic tree was obtained with MEGA4 software (http://megasoftware.net) using the ITS-rDNA sequence of $S$. coffeicola as an outgroup.

Pathogenicity assays. Pathogenicity of the $S$. rolfsii isolates was assessed on Arachis hypogaea L. 'L14', the predominant groundnut cultivar grown in Vietnam. In total, $18 \mathrm{~S}$. rolfsii isolates, selected based on origin (i.e., groundnut $[n=8]$, tomato $[n=5]$ and taro $[n=5])$ and ITS group, were tested for pathogenicity. A single

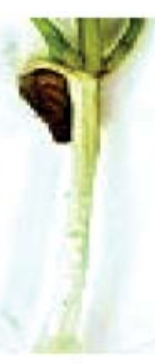

0

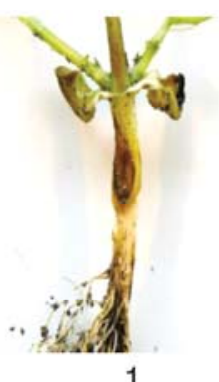

1

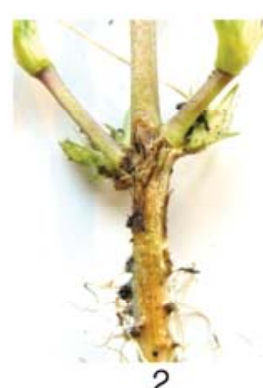

2



3



4

Fig. 2. Disease scales of groundnut infected by Sclerotium rolfsii; $0=$ no disease symptoms, $1=$ disease symptoms without visible outgrowth of the fungus, $2=$ disease symptoms with visible outgrowth, $3=$ partial wilting of the plant, and $4=$ complete wilting and plant death.
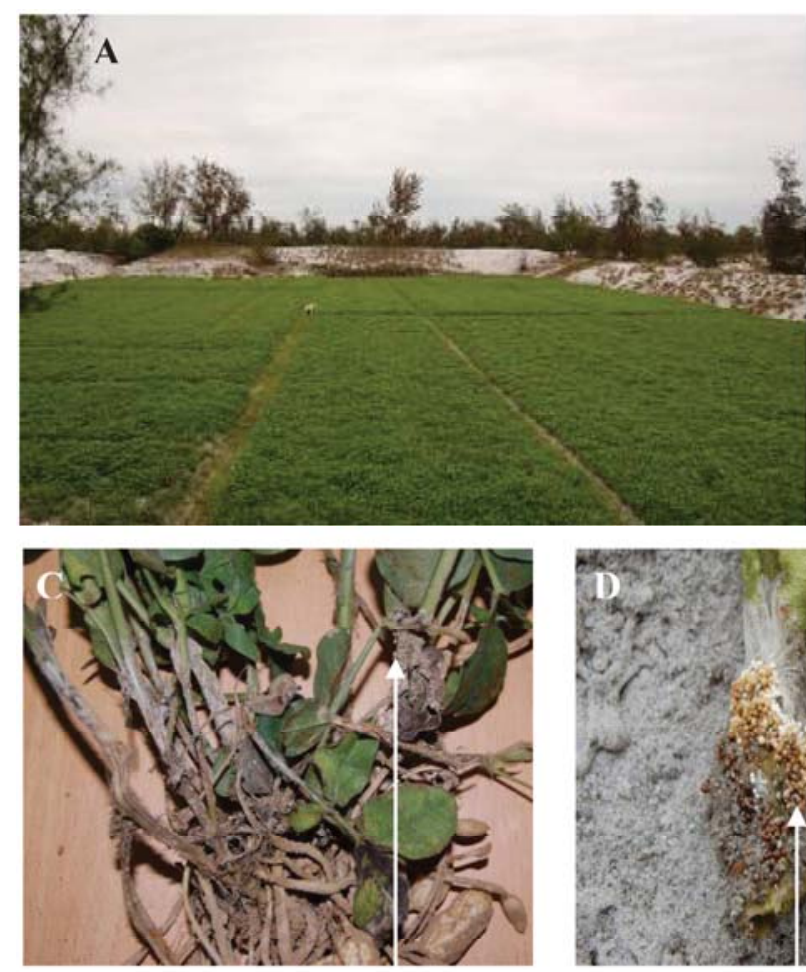

Sclerotia

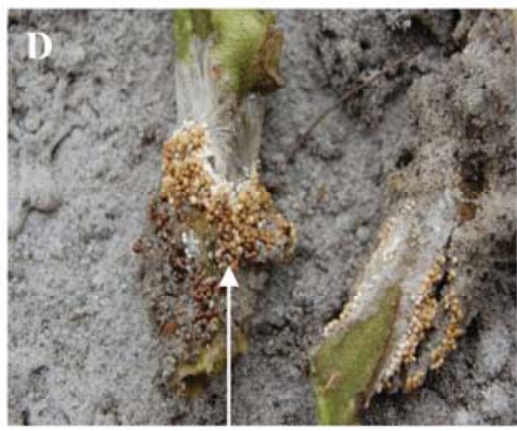

Sclerotia
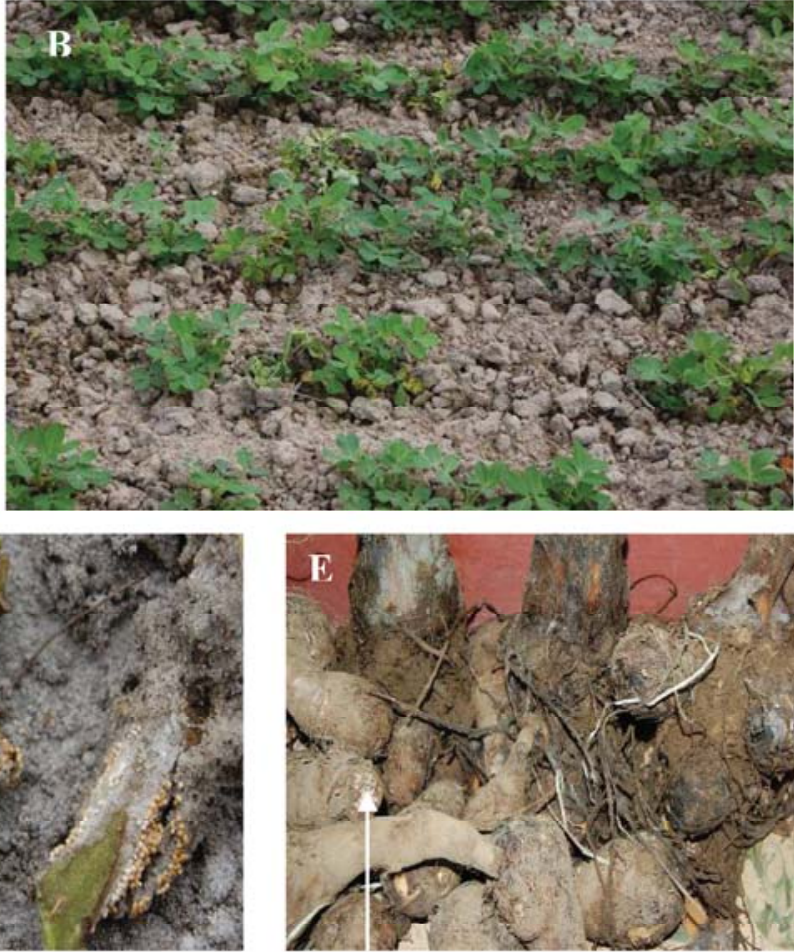

Sclerotia

Fig. 3. A, Overview of the sampling location in Quang Nam province; B, effects of Sclerotium rolfsii on emergence and growth of groundnut seedlings in the field; and symptoms of stem rot of $\mathbf{C}$, groundnut; $\mathbf{D}$, tomato; and $\mathbf{E}$, taro. The sclerotia on the infected plant tissues are indicated by an arrow. 
groundnut seed was sown in a square plastic pot $(6 \mathrm{~cm}$ in width by $8 \mathrm{~cm}$ in height) containing $250 \mathrm{~g}$ of natural field soil obtained from Hue (Vietnam). Pots were placed in a nethouse and watered regularly. One week after sowing, a mycelial plug (1 cm in diameter) of a 3-day-old $S$. rolfsii PDA plate culture was placed at the base of the stem. Disease incidence and severity were determined 2 weeks after fungal inoculation. Disease incidence refers to the percentage of diseased plants and disease severity was rated on a scale from 0 to 4 , with $0=$ no disease symptoms, $1=$ disease symptoms without visible fungal outgrowth, 2 = disease symptoms with visible fungal outgrowth, $3=$ partial wilting of the plant, and $4=$ complete wilting and plant death (Fig. 2). For each $S$. rolfsii isolate, three trays with five pots (one plant per pot) each were used.

Phenotypic characterization. $S$. rolfsii isolates were cultured on PDA plates at $25^{\circ} \mathrm{C}$. Per isolate, two $25-\mathrm{ml}$ PDA agar plates $(9 \mathrm{~cm}$ in diameter) were inoculated in the center with a mycelial plug $(5 \mathrm{~mm}$ in diameter), and radial mycelial growth of the fungal colony was determined $48 \mathrm{~h}$ after incubation. For each plate, the number of sclerotia was determined 21 days after incubation and the sclerotial diameter was determined for 30 randomly selected sclerotia.

In total, 26 randomly selected $S$. rolfsii isolates were tested for mycelial compatibility. Multiple combinations of two isolates of $S$. rolfsii were inoculated on PDA plates and incubated at $25^{\circ} \mathrm{C}$ for 2 weeks. Mycelial compatibility was assessed macroscopically by the method of Punja and Grogan (30). If there was a distinct barrage zone at the contact area between two isolates, these isolates were considered to belong to a different mycelial compatibility group (MCG).
The ergosterol biosynthesis inhibitor fungicide tebuconazole is widely used to control $S$. rolfsii. In our study, $S$. rolfsii isolates were cultured in duplicate on PDA amended with tebuconazole (Sigma-Aldrich Chemie B.V.) to final concentrations of $0,0.02$, and $0.2 \mathrm{mg} \mathrm{liter}^{-1}$. Hyphal growth was assessed $48 \mathrm{~h}$ after incubation at $25^{\circ} \mathrm{C}$. Sensitivity of $S$. rolfsii to tebuconazole was calculated with the formula used by Franke et al. (14): inhibition $(\%)=100-$ [(colony diameter on amended medium/colony diameter on control medium $) \times 100$ ].

\section{Results}

Disease incidence. Our survey showed that the incidence of stem rot of groundnut caused by $S$. rolfsii ranged from approximately 5 to $25 \%$ (Figs. 1 and 3). Furthermore, a gradient in stem rot disease incidence was observed across central Vietnam with an increase in disease incidence from the northern to the southern field sites (Fig. 1). This might be related to the effect of temperature on disease development (28) because, along with the lower latitude, the average daily temperature increases from the north to the south of Vietnam. For two of the four provinces (i.e., locations $\mathrm{B}$ and $\mathrm{C}$ ), the disease incidence of groundnut plants cultivated in clay loam soil was significantly higher than in sandy soil (Fig. 1).

Genetic diversity of $\boldsymbol{S}$. rolfsii. In total, 198 purified $S$. rolfsii isolates, obtained from more than 400 randomly collected samples from different host plants (groundnut, tomato, and taro) in the four provinces and in the remote upland region were subjected to ITSrDNA sequence analysis. For $103 \mathrm{~S}$. rolfsii isolates, high-quality forward and reverse sequences were obtained whereas, for the

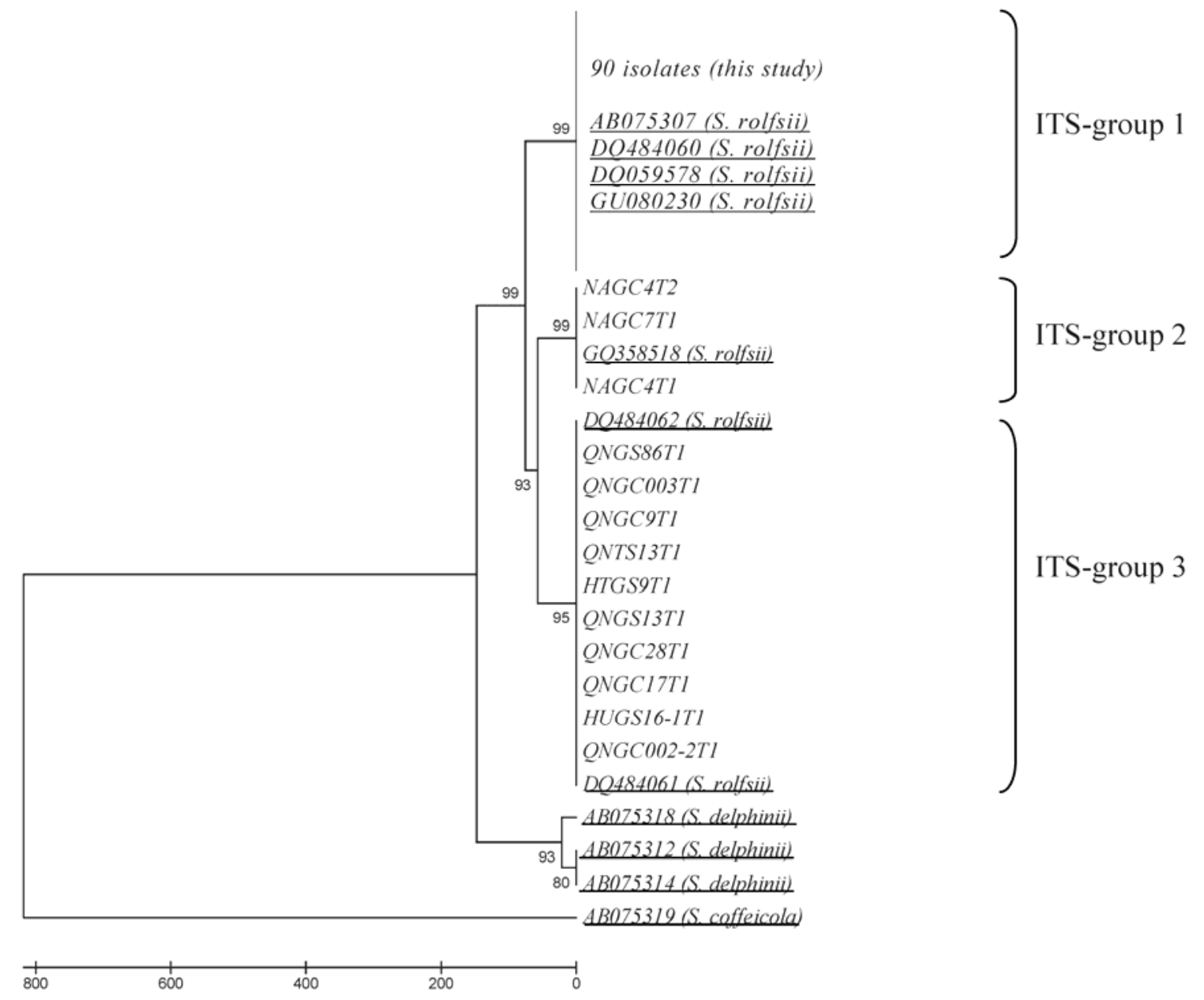

Fig. 4. Phylogeny of internal transcribed spacer (ITS) ribosomal DNA sequences of Sclerotium rolfsii isolates from groundnut fields in central Vietnam and of reference strains of S. rolfsii, S. delphinii, and S. coffeicola (underlined, see Table 1) using the unweighted pair-group method. Bootstrap values with 1,000 replications are indicated at the nodes of the branches. The bar represents the evolutionary distances computed using the maximum composite likelihood method. Sequence codes of the isolates collected in this study refer to the province (first two letters), host crop (third letter), soil type (fourth letter), and the isolate number (digits): NA = Nghe An province, HT = Ha Tinh province, $\mathrm{HU}=$ Thua Thien Hue province, $\mathrm{QN}=$ Quang Nam province; $\mathrm{G}=$ groundnut, $\mathrm{T}=$ tomato, $\mathrm{M}=$ taro; $\mathrm{C}=$ clay loam soil, $\mathrm{S}=$ sandy soil. 
other 95 isolates, discrepancies were observed in the assembly of the forward and reverse sequences. Resequencing of the ITS fragments of 12 selected isolates did not resolve this inconsistency, which may suggest polymorphisms in different ITS copies in each of these isolates. ITS polymorphisms within a single isolate have been found for several fungal genera and were also reported earlier for $S$. rolfsii by Okabe et al. $(24,26)$.

Phylogenetic analysis of the ITS-rDNA sequences of the reference isolates of $S$. rolfsii (i.e., isolates for which ITS-rDNA sequences are present in the National Center for Biotechnology Information database; Table 1), revealed three main groups designated ITS groups 1 to 3 (Fig. 4). Most isolates $(n=90)$ collected from central Vietnam belong to ITS group 1 and were identical to reference isolates of $S$. rolfsii that were previously collected from groundnut, tobacco, and sweet pepper (Fig. 4; Table 1). The three isolates in ITS group 2 were collected from the remote upland region of Nghe An province (Fig. 4) and cluster with an $S$. rolfsii isolate collected from Ascocenda orchids in Florida (12). Of the 10 isolates in ITS group 3, 8 were collected in Quang Nam province (Fig. 4). Collectively, these results suggest that the $S$. rolfsii population in groundnut fields in central Vietnam appears relatively uniform. To get more insight into the intraspecific diversity of the collection of $S$. rolfsii isolates from central Vietnam, a range of other traits, including pathogenicity, growth rate, sclerotial characteristics, mycelial compatibility, and tebuconazole sensitivity, were analyzed.

Pathogenicity. Pathogenicity assays showed that $S$. rolfsii isolates obtained from groundnut $(n=8)$, tomato $(n=5)$, and taro $(n=$ 5 ) and representing ITS groups 1 to 3 were all pathogenic on groundnut (Table 2). The time for the first symptoms to appear

Table 2. Pathogenicity of Sclerotium rolfsii isolates on groundnut ${ }^{\mathrm{a}}$

\begin{tabular}{lcccc}
\hline Host crop & $\begin{array}{c}\text { ITS } \\
\text { group }^{\mathbf{b}}\end{array}$ & $\begin{array}{c}\text { Incubation } \\
(\mathbf{d a y})^{\mathbf{c}}\end{array}$ & $\begin{array}{c}\text { Incidence } \\
\mathbf{( \% )}^{\mathbf{d}}\end{array}$ & $\begin{array}{c}\text { Severity } \pm \text { SE } \\
(\boldsymbol{\%})^{\mathbf{e}}\end{array}$ \\
\hline Groundnut $(n=5)$ & 1,3 & $2-3$ & 100 & $92.7 \pm 2.21$ \\
Tomato $(n=5)$ & 1,3 & $4-5$ & 100 & $86.3 \pm 4.26$ \\
Taro $(n=5)$ & 1 & $3-4$ & 100 & $95.3 \pm 1.11$ \\
Groundnut $(n=3)$ & 2 & $3-4$ & 100 & $75.0 \pm 2.89$ \\
\hline
\end{tabular}

${ }^{a}$ Isolates used for these assays are indicated in Table 4 with an asterisk.

${ }^{\mathrm{b}}$ Internal transcribed spacer (ITS) group as indicated in Figure 4.

${ }^{\mathrm{c}}$ Incubation period $=$ days to first symptom appearance after fungal inoculation.

${ }^{\mathrm{d}}$ Disease incidence $(\%)=($ diseased plants/total number of plants $) \times 100 \%$.

${ }^{\mathrm{e}}$ Disease severity \pm standard error (SE): diseased plants were ranked on a 0 -to-4 scale based on the symptoms, with $0=$ no disease symptoms, $1=$ disease symptoms without visible outgrowth of the fungus, $2=$ disease symptoms with visible outgrowth, $3=$ partial wilting of the plant, and $4=$ complete wilting and plant death. Disease severity $(\%)=[(1 \times$ number of plants classified in scale 1$)+(2 \times$ number of plants classified in scale 2$)+$ $(3 \times$ number of plants classified in scale 3$)+(4 \times$ number of plants classified in scale 4$)] \times 100 \% /(4 \times$ total number of plants $)]$. ranged from 2 to 5 days; however, no statistically significant differences (analysis of variance, $P<0.05$ ) in disease incidence and severity were found between the isolates (Table 2). These results confirmed pathogenicity of (i) a subset of $S$. rolfsii isolates collected from groundnut, (ii) all $S$. rolfsii isolates collected from other crops (i.e., tomato and taro), and (iii) the three isolates collected from groundnut cultivated in the remote upland region in Nghe An province (ITS group 2).

Growth rate and sclerotial characteristics. $S$. rolfsii is notorious for its high growth rate in vitro $(2,28,29)$. Indeed, the 103 Vietnamese isolates tested here exhibited a high growth rate of 0.28 to $0.79 \mathrm{~mm} \mathrm{~h}^{-1}$ (Tables 3 and 4). On average, isolates from ITS groups 1,2 , and 3 showed no significant differences in growth rate (Table 3). On PDA, the $S$. rolfsii isolates produced typical silkywhite mycelium and brown or dark brown sclerotia (Fig. 5; 16). For the 103 isolates tested, considerable variation was observed in the time to form sclerotia, their maturation time, and their number and size (Tables 3 and 4). For example, the number of sclerotia formed per plate after 21 days of incubation ranged from 79 to 1,080 and their size from 0.88 to $2.24 \mathrm{~mm}$ (Table 3 ). When comparing the sclerotial traits, the three isolates in ITS group 2 were different from the isolates in ITS groups 1 and 3 (Table 3). ITS group 2 isolates produced substantially fewer sclerotia per plate; also, the average maturation time and sclerotial diameter were approximately two times greater than for isolates of ITS groups 1 and 3.

Mycelial compatibility. Within each of the three ITS groups identified in our study, a high variation in mycelial compatibility was observed (Table 5). For isolates of ITS group 1, 91 combinations were tested and only $6.6 \%$ of these combinations showed a compatible interaction pointing to at least nine MCGs. For ITS groups 2 and 3, we found two and six MCGs, respectively (Table $5)$.

Tebuconazole sensitivity. At a tebuconazole concentration of $0.02 \mathrm{mg} \mathrm{liter}^{-1}$, the inhibition of mycelial growth of the $103 \mathrm{~S}$. rolfsii isolates from Vietnam ranged from 18.2 to $58.8 \%$, with an overall average of $36.5 \%$ (Tables 4 and 6). The three isolates from ITS group 2, collected from the remote upland region, were significantly more sensitive to tebuconazole than those from ITS group 1 (Table 6). In the study by Franke et al. (14), the variation in tebuconazole sensitivity of $S$. rolfsii isolates from Georgia was substantially higher: at the same tebuconazole concentration of $0.02 \mathrm{mg}$ liter $^{-1}$, inhibition of mycelial growth of 473 field isolates ranged from -54 to $79 \%$ with an overall average of $28 \%$; several isolates from their collection showed negative inhibition values, which presumably reflects a positive effect of tebuconazole on hyphal growth.

\section{Discussion}

$S$. rolfsii Sacc. is a major soilborne pathogen of groundnut. Fundamental knowledge of the diversity and epidemiology of $S$. rolfsii

Table 3. Growth rate and sclerotial characteristics of Sclerotium rolfsii isolates obtained from groundnut fields in central Vietnam

\begin{tabular}{|c|c|c|c|c|c|}
\hline \multirow[b]{2}{*}{ Characteristics } & \multirow[b]{2}{*}{ Growth $\left(\mathrm{mm} \mathrm{h}^{-1}\right)^{\mathbf{a}}$} & \multicolumn{4}{|c|}{ Sclerotia production and size } \\
\hline & & Days to form & Days to mature & Number per plate & Diameter (mm) \\
\hline \multicolumn{6}{|l|}{ Values ${ }^{b}$} \\
\hline Average & 0.40 & 4.8 & 8.0 & 589 & 1.1 \\
\hline Minimum & 0.28 & 4.0 & 7.0 & 79 & 0.9 \\
\hline Maximum & 0.79 & 11.0 & 16.0 & 1080 & 2.2 \\
\hline Standard deviation & 0.06 & 1.1 & 1.4 & 204 & 0.2 \\
\hline \multicolumn{6}{|l|}{ ITS group ${ }^{c}$} \\
\hline $1(n=90)$ & $0.41 \pm 0.06$ & $4.7 \pm 0.6$ & $7.8 \pm 0.7$ & $595 \pm 181$ & $1.1 \pm 0.1$ \\
\hline $2(n=3)$ & $0.36 \pm 0.04$ & $10.0 \pm 1.7$ & $14.3 \pm 2.9$ & $98 \pm 16$ & $2.0 \pm 0.2$ \\
\hline $3(n=10)$ & $0.41 \pm 0.04$ & $4.2 \pm 0.4$ & $7.8 \pm 1.2$ & $689 \pm 236$ & $1.1 \pm 0.2$ \\
\hline Average & $0.40 \pm 0.06$ & $4.8 \pm 1.1$ & $8.0 \pm 1.4$ & $589 \pm 204$ & $1.1 \pm 0.2$ \\
\hline
\end{tabular}

a Hyphal growth rate during $48 \mathrm{~h}$.

${ }^{\mathrm{b}}$ Averages, minimum, and maximum values of each of these phenotypic characteristics are given for 103 isolates.

${ }^{c}$ Averages \pm the standard deviation of these phenotypic characteristics are given for each of the three identified internal transcribed spacer (ITS) ribosomal DNA groups of $S$. rolfsii. 
Table 4. Genetic and phenotypic traits of 103 randomly selected Sclerotium rolfsii isolates from groundnut fields in central Vietnam ${ }^{\mathrm{a}}$

\begin{tabular}{|c|c|c|c|c|c|c|c|c|c|c|c|c|c|c|}
\hline \multirow[b]{2}{*}{ Order } & \multirow[b]{2}{*}{ Code } & \multicolumn{3}{|c|}{ Origin } & \multirow[b]{2}{*}{ ITS $^{\mathbf{c}}$} & \multirow[b]{2}{*}{ Rate $(\mathbf{m m} / \mathbf{h})^{\mathbf{d}}$} & \multicolumn{2}{|c|}{ Time (days) } & \multicolumn{4}{|c|}{ Diameter of sclerotia $(\mathbf{m m})^{\text {b }}$} & \multirow[b]{2}{*}{ Sclerotiag } & \multirow[b]{2}{*}{ Inhib. $(\%)^{\mathrm{h}}$} \\
\hline & & Province & Soil & Host & & & Produce $^{\mathrm{e}}$ & Mature $^{f}$ & Avg & Min & Max & SD & & \\
\hline 1 & HTGS12T1 & Ha Tinh & Sandy & Groundnut & 1 & 0.43 & 5 & 8 & 1.06 & 0.71 & 1.32 & 0.16 & 1,080 & 19.80 \\
\hline 2 & HTGS13-2T1 & Ha Tinh & Sandy & Groundnut & 1 & 0.36 & 5 & 8 & 0.89 & 0.58 & 1.35 & 0.19 & 618 & 26.26 \\
\hline 3 & HTGS17T1 & Ha Tinh & Sandy & Groundnut & 1 & 0.32 & 6 & 9 & 1.29 & 1.02 & 1.57 & 0.16 & 278 & 22.77 \\
\hline 4 & HTGS18T1 & Ha Tinh & Sandy & Groundnut & 1 & 0.42 & 4 & 7 & 0.99 & 0.72 & 1.26 & 0.13 & 616 & 37.58 \\
\hline 5 & HTGS20T1 & Ha Tinh & Sandy & Groundnut & 1 & 0.37 & 5 & 8 & 1.14 & 0.80 & 1.65 & 0.20 & 508 & 28.19 \\
\hline 6 & HTGS23T1 & Ha Tinh & Sandy & Groundnut & 1 & 0.36 & 4 & 8 & 0.93 & 0.67 & 1.17 & 0.12 & 658 & 47.70 \\
\hline 7 & HTGS24T1 & Ha Tinh & Sandy & Groundnut & 1 & 0.39 & 5 & 8 & 1.22 & 0.78 & 1.43 & 0.16 & 326 & 38.04 \\
\hline 8 & HTGS6T1 & Ha Tinh & Sandy & Groundnut & 1 & 0.34 & 5 & 8 & 1.00 & 0.68 & 1.37 & 0.14 & 724 & 50.07 \\
\hline 9 & HTGS9T1 & Ha Tinh & Sandy & Groundnut & 3 & 0.35 & 5 & 8 & 1.02 & 0.72 & 1.37 & 0.19 & 584 & 45.40 \\
\hline 10 & HTGC10-2T1 & Ha Tinh & Clay loam & Groundnut & 1 & 0.41 & 4 & 7 & 1.20 & 0.86 & 1.53 & 0.18 & 568 & 36.29 \\
\hline 11 & HTGC10-1T1 & Ha Tinh & Clay loam & Groundnut & 1 & 0.36 & 5 & 9 & 1.07 & 0.77 & 1.40 & 0.19 & 516 & 24.25 \\
\hline 12 & HTGC13-1T1 & Ha Tinh & Clay loam & Groundnut & 1 & 0.41 & 5 & 8 & 1.10 & 0.85 & 1.47 & 0.16 & 452 & 42.31 \\
\hline 13 & HTGC13T1 & Ha Tinh & Clay loam & Groundnut & 1 & 0.33 & 5 & 8 & 1.09 & 0.67 & 1.43 & 0.19 & 472 & 28.09 \\
\hline 14 & HTGC3T1 & Ha Tinh & Clay loam & Groundnut & 1 & 0.40 & 4 & 7 & 1.06 & 0.81 & 1.29 & 0.12 & 704 & 38.34 \\
\hline 15 & HTGC5T1 & Ha Tinh & Clay loam & Groundnut & 1 & 0.38 & 5 & 8 & 1.29 & 0.90 & 1.57 & 0.17 & 346 & 19.85 \\
\hline 16 & HTGC9T1 & Ha Tinh & Clay loam & Groundnut & 1 & 0.45 & 4 & 7 & 1.24 & 0.90 & 1.72 & 0.18 & 356 & 53.90 \\
\hline 17 & HTGC9T2 & Ha Tinh & Clay loam & Groundnut & 1 & 0.44 & 4 & 7 & 1.21 & 0.99 & 1.55 & 0.12 & 422 & 42.70 \\
\hline 18 & NAGS2-1T1 & Nghe An & Sandy & Groundnut & 1 & 0.42 & 5 & 8 & 1.09 & 0.64 & 1.50 & 0.25 & 576 & 30.06 \\
\hline 19 & NAGS1T1 * & Nghe An & Sandy & Groundnut & 1 & 0.40 & 4 & 8 & 1.04 & 0.84 & 1.29 & 0.13 & 472 & 31.97 \\
\hline 20 & NAGS5T1 & Nghe An & Sandy & Groundnut & 1 & 0.42 & 4 & 7 & 1.09 & 0.84 & 1.77 & 0.18 & 688 & 41.64 \\
\hline 21 & NAGC10T1 & Nghe An & Clay loam & Groundnut & 1 & 0.42 & 5 & 8 & 0.98 & 0.67 & 1.35 & 0.19 & 574 & 51.92 \\
\hline 22 & NAGC12T1 & Nghe An & Clay loam & Groundnut & 1 & 0.35 & 6 & 10 & 1.47 & 1.00 & 2.05 & 0.27 & 184 & 25.61 \\
\hline 23 & NAGC15T1 & Nghe An & Clay loam & Groundnut & 1 & 0.41 & 5 & 8 & 1.14 & 0.75 & 1.69 & 0.22 & 464 & 35.90 \\
\hline 24 & NAGC18T1 & Nghe An & Clay loam & Groundnut & 1 & 0.35 & 6 & 10 & 1.23 & 0.99 & 1.61 & 0.15 & 282 & 25.13 \\
\hline 25 & NAGC1T1 & Nghe An & Clay loam & Groundnut & 1 & 0.39 & 5 & 8 & 1.12 & 0.79 & 1.40 & 0.16 & 538 & 34.52 \\
\hline 26 & NAGC21T1 & Nghe An & Clay loam & Groundnut & 1 & 0.38 & 4 & 7 & 1.09 & 0.87 & 1.44 & 0.14 & 564 & 39.42 \\
\hline 27 & NAGC22T1 & Nghe An & Clay loam & Groundnut & 1 & 0.35 & 5 & 8 & 1.08 & 0.87 & 1.40 & 0.12 & 542 & 43.80 \\
\hline 28 & NAGC2-2T1 & Nghe An & Clay loam & Groundnut & 1 & 0.35 & 5 & 7 & 1.02 & 0.76 & 1.45 & 0.13 & 605 & 29.17 \\
\hline 29 & NAGC27T1 & Nghe An & Clay loam & Groundnut & 1 & 0.41 & 5 & 8 & 1.00 & 0.75 & 1.20 & 0.13 & 880 & 38.23 \\
\hline 30 & NAGC9T1 & Nghe An & Clay loam & Groundnut & 1 & 0.37 & 6 & 9 & 1.23 & 0.75 & 1.59 & 0.20 & 337 & 27.75 \\
\hline 31 & NAGC4T1 * & Nghe An & Clay loam & Groundnut & 2 & 0.32 & 11 & 16 & 1.91 & 0.85 & 3.42 & 0.58 & 105 & 45.65 \\
\hline 32 & NAGC4T2 $*$ & Nghe An & Clay loam & Groundnut & 2 & 0.28 & 11 & 16 & 2.24 & 1.08 & 3.39 & 0.73 & 79 & 49.02 \\
\hline 33 & NAGC13T1 & Nghe An & Clay loam & Groundnut & 1 & 0.35 & 5 & 8 & 1.05 & 0.80 & 1.37 & 0.14 & 532 & 26.76 \\
\hline 34 & NAGC7T1 $*$ & Nghe An & Clay loam & Groundnut & 2 & 0.35 & 8 & 11 & 1.97 & 1.20 & 3.19 & 0.53 & 110 & 42.89 \\
\hline 35 & NATC1T1 * & Nghe An & Clay loam & Tomato & 1 & 0.42 & 4 & 7 & 1.15 & 0.74 & 1.41 & 0.16 & 626 & 53.66 \\
\hline 36 & QNGS38-2T1 & Quang Nam & Sandy & Groundnut & 1 & 0.46 & 5 & 8 & 1.17 & 0.79 & 1.50 & 0.18 & 470 & 29.48 \\
\hline 37 & QNGS52T1 & Quang Nam & Sandy & Groundnut & 1 & 0.45 & 5 & 8 & 1.20 & 0.93 & 1.56 & 0.16 & 428 & 43.90 \\
\hline 38 & QNGS1T1 & Quang Nam & Sandy & Groundnut & 1 & 0.40 & 5 & 8 & 1.14 & 0.81 & 1.41 & 0.16 & 664 & 23.75 \\
\hline 39 & QNGC86T1 & Quang Nam & Sandy & Groundnut & 3 & 0.45 & 4 & 8 & 0.90 & 0.53 & 1.20 & 0.13 & 696 & 41.76 \\
\hline 40 & QNGS17T1 & Quang Nam & Sandy & Groundnut & 1 & 0.38 & 5 & 8 & 1.11 & 0.70 & 1.53 & 0.19 & 546 & 34.69 \\
\hline 41 & QNGS23T1 & Quang Nam & Sandy & Groundnut & 1 & 0.40 & 4 & 8 & 1.08 & 0.76 & 1.28 & 0.13 & 656 & 49.99 \\
\hline 42 & QNGS2T1 & Quang Nam & Sandy & Groundnut & 1 & 0.42 & 5 & 8 & 1.12 & 0.82 & 1.50 & 0.16 & 548 & 31.94 \\
\hline 43 & QNGS7T1 & Quang Nam & Sandy & Groundnut & 1 & 0.40 & 5 & 8 & 1.12 & 0.79 & 1.52 & 0.20 & 474 & 35.19 \\
\hline 44 & QNGS38T1 & Quang Nam & Sandy & Groundnut & 1 & 0.39 & 5 & 8 & 1.07 & 0.83 & 1.39 & 0.16 & 604 & 38.85 \\
\hline 45 & QNGS40T1 & Quang Nam & Sandy & Groundnut & 1 & 0.38 & 5 & 8 & 1.07 & 0.72 & 1.31 & 0.16 & 672 & 34.61 \\
\hline 46 & QNGS13T1 & Quang Nam & Sandy & Groundnut & 3 & 0.43 & 4 & 7 & 1.09 & 0.83 & 1.31 & 0.14 & 822 & 28.64 \\
\hline 47 & QNGS3T1 & Quang Nam & Sandy & Groundnut & 1 & 0.40 & 5 & 8 & 1.11 & 0.85 & 1.49 & 0.18 & 646 & 41.15 \\
\hline 48 & QNGS8T1 & Quang Nam & Sandy & Groundnut & 1 & 0.44 & 4 & 7 & 1.09 & 0.69 & 1.52 & 0.22 & 430 & 31.86 \\
\hline 49 & QNMS25T1* & Quang Nam & Sandy & Taro & 1 & 0.48 & 4 & 7 & 1.14 & 0.76 & 1.48 & 0.16 & 492 & 38.19 \\
\hline 50 & QNTS13T1* & Quang Nam & Sandy & Tomato & 3 & 0.42 & 4 & 7 & 0.95 & 0.78 & 1.15 & 0.08 & 978 & 22.77 \\
\hline 51 & QNGC002-2T1 & Quang Nam & Clay loam & Groundnut & 3 & 0.43 & 4 & 7 & 1.00 & 0.78 & 1.24 & 0.12 & 808 & 41.87 \\
\hline 52 & QNGC17T1 & Quang Nam & Clay loam & Groundnut & 3 & 0.37 & 4 & 8 & 1.10 & 0.95 & 1.40 & 0.12 & 844 & 56.00 \\
\hline 53 & QNGC61T1 & Quang Nam & Clay loam & Groundnut & 1 & 0.39 & 4 & 8 & 1.19 & 0.86 & 1.42 & 0.15 & 614 & 32.98 \\
\hline 54 & QNGC73T1 & Quang Nam & Clay loam & Groundnut & 1 & 0.35 & 5 & 8 & 1.21 & 0.89 & 1.48 & 0.15 & 544 & 35.96 \\
\hline 55 & QNGC19-2T1 & Quang Nam & Clay loam & Groundnut & 1 & 0.40 & 4 & 7 & 1.11 & 0.83 & 1.29 & 0.12 & 578 & 37.99 \\
\hline 56 & QNGC49T1 & Quang Nam & Clay loam & Groundnut & 1 & 0.43 & 4 & 7 & 1.09 & 0.71 & 1.59 & 0.19 & 592 & 46.54 \\
\hline 57 & QNGC003T1 & Quang Nam & Clay loam & Groundnut & 3 & 0.33 & 5 & 11 & 1.72 & 1.04 & 2.54 & 0.41 & 136 & 58.82 \\
\hline 58 & QNGC16T1 & Quang Nam & Clay loam & Groundnut & 1 & 0.79 & 5 & 8 & 1.09 & 0.84 & 1.39 & 0.14 & 360 & 31.84 \\
\hline 59 & QNGC26T1 & Quang Nam & Clay loam & Groundnut & 1 & 0.34 & 5 & 7 & 0.96 & 0.77 & 1.33 & 0.13 & 682 & 42.38 \\
\hline 60 & QNGC28T1 & Quang Nam & Clay loam & Groundnut & 3 & 0.46 & 4 & 8 & 1.04 & 0.59 & 1.25 & 0.16 & 522 & 33.37 \\
\hline 61 & QNGC3T1 & Quang Nam & Clay loam & Groundnut & 1 & 0.43 & 4 & 7 & 0.96 & 0.81 & 1.21 & 0.09 & 716 & 27.20 \\
\hline 62 & QNGC5T1* & Quang Nam & Clay loam & Groundnut & 1 & 0.38 & 4 & 8 & 1.05 & 0.88 & 1.35 & 0.11 & 754 & 34.00 \\
\hline 63 & QNGC6T1 & Quang Nam & Clay loam & Groundnut & 1 & 0.39 & 5 & 8 & 1.10 & 0.77 & 1.34 & 0.13 & 732 & 37.55 \\
\hline & & & & & & & & & & & & & (continue & next page) \\
\hline
\end{tabular}

\footnotetext{
${ }^{a}$ Isolates used in the pathogenicity assays are indicated with an asterisk; isolates from the remote upland area of Nghe An province are underlined.

${ }^{\mathrm{b}}$ Average (Avg), minimum (Min), maximum (Max), and standard deviation (SD).

${ }^{\mathrm{c}}$ Internal transcribed spacer (ITS) group.

${ }^{\mathrm{d}}$ Mycelial growth rate during $48 \mathrm{~h}(\mathrm{~mm} / \mathrm{h})$.

e Time to produce sclerotia.

${ }^{\mathrm{f}}$ Time for maturation of the sclerotia.

g Number of sclerotia per plate.

${ }^{\mathrm{h}}$ Sensitivity to tebuconazole at $0.02 \mathrm{mg} /$ liter (percent inhibition).
} 
Table 4. (continued from preceding page)

\begin{tabular}{|c|c|c|c|c|c|c|c|c|c|c|c|c|c|c|}
\hline \multirow[b]{2}{*}{ Order } & \multirow[b]{2}{*}{ Code } & \multicolumn{3}{|c|}{ Origin } & \multirow[b]{2}{*}{ ITS $^{\mathbf{c}}$} & \multirow[b]{2}{*}{ Rate $(\mathbf{m m} / \mathbf{h})^{\mathbf{d}}$} & \multicolumn{2}{|c|}{ Time (days) } & \multicolumn{4}{|c|}{ Diameter of sclerotia $(\mathbf{m m})^{b}$} & \multirow[b]{2}{*}{ Sclerotia $^{\mathrm{g}}$} & \multirow[b]{2}{*}{ Inhib. $(\%)^{\mathrm{h}}$} \\
\hline & & Province & Soil & Host & & & Produce $^{\mathrm{e}}$ & Mature $^{\mathrm{f}}$ & Avg & Min & Max & SD & & \\
\hline 64 & QNGC7T1 & Quang Nam & Clay loam & Groundnut & 1 & 0.39 & 5 & 8 & 1.18 & 0.88 & 1.49 & 0.14 & 546 & 37.03 \\
\hline 65 & QNGC9T1 & Quang Nam & Clay loam & Groundnut & 3 & 0.41 & 4 & 7 & 0.96 & 0.74 & 1.56 & 0.18 & 844 & 48.56 \\
\hline 66 & QNGC22T1 & Quang Nam & Clay loam & Groundnut & 1 & 0.45 & 5 & 8 & 1.15 & 0.81 & 1.67 & 0.23 & 530 & 51.76 \\
\hline 67 & HUGS12T1 & Thua Thien Hue & Sandy & Groundnut & 1 & 0.46 & 7 & 11 & 1.07 & 0.86 & 1.41 & 0.15 & 520 & 38.59 \\
\hline 68 & HUGS11T2 & Thua Thien Hue & Sandy & Groundnut & 1 & 0.42 & 5 & 8 & 1.04 & 0.73 & 1.36 & 0.14 & 582 & 27.29 \\
\hline 69 & HUGS13T1 & Thua Thien Hue & Sandy & Groundnut & 1 & 0.37 & 5 & 8 & 1.09 & 0.83 & 1.28 & 0.11 & 638 & 45.72 \\
\hline 70 & HUGS14T1 & Thua Thien Hue & Sandy & Groundnut & 1 & 0.38 & 4 & 8 & 1.16 & 0.82 & 1.36 & 0.12 & 616 & 39.74 \\
\hline 71 & HUGS16-1T1 & Thua Thien Hue & Sandy & Groundnut & 3 & 0.46 & 4 & 7 & 1.05 & 0.66 & 1.44 & 0.18 & 652 & 49.36 \\
\hline 72 & HUGS1T1 & Thua Thien Hue & Sandy & Groundnut & 1 & 0.41 & 4 & 8 & 1.33 & 0.87 & 1.60 & 0.17 & 368 & 19.63 \\
\hline 73 & HUGS6T1 & Thua Thien Hue & Sandy & Groundnut & 1 & 0.40 & 4 & 7 & 1.03 & 0.76 & 1.23 & 0.12 & 726 & 43.08 \\
\hline 74 & HUGS4T1 & Thua Thien Hue & Sandy & Groundnut & 1 & 0.42 & 4 & 7 & 1.09 & 0.59 & 1.33 & 0.19 & 488 & 40.58 \\
\hline 75 & HUGS5T1 & Thua Thien Hue & Sandy & Groundnut & 1 & 0.39 & 5 & 8 & 1.05 & 0.64 & 1.44 & 0.20 & 578 & 37.77 \\
\hline 76 & HUGS16-2T1 & Thua Thien Hue & Sandy & Groundnut & 1 & 0.45 & 4 & 7 & 1.14 & 0.80 & 1.36 & 0.13 & 476 & 27.17 \\
\hline 77 & HUGS7T1 & Thua Thien Hue & Sandy & Groundnut & 1 & 0.40 & 4 & 8 & 1.08 & 0.71 & 1.41 & 0.17 & 930 & 27.78 \\
\hline 78 & HUGS18T1 & Thua Thien Hue & Sandy & Groundnut & 1 & 0.41 & 4 & 7 & 0.90 & 0.70 & 1.25 & 0.15 & 932 & 36.81 \\
\hline 79 & HUGS18T2 & Thua Thien Hue & Sandy & Groundnut & 1 & 0.42 & 4 & 7 & 1.03 & 0.83 & 1.35 & 0.14 & 954 & 55.54 \\
\hline 80 & RH001 & Thua Thien Hue & Sandy & Groundnut & 1 & 0.42 & 4 & 7 & 1.14 & 0.89 & 1.57 & 0.18 & 508 & 38.96 \\
\hline 81 & H001 & Thua Thien Hue & Sandy & Groundnut & 1 & 0.45 & 5 & 8 & 1.23 & 0.76 & 1.55 & 0.17 & 338 & 23.42 \\
\hline 82 & HUMC22T1 * & Thua Thien Hue & Sandy & Taro & 1 & 0.40 & 4 & 7 & 1.16 & 0.85 & 1.70 & 0.18 & 495 & 22.27 \\
\hline 83 & HUTS1T2 * & Thua Thien Hue & Sandy & Tomato & 1 & 0.41 & 4 & 7 & 1.05 & 0.68 & 1.41 & 0.12 & 562 & 49.78 \\
\hline 84 & HUGC10-1T1 & Thua Thien Hue & Clay loam & Groundnut & 1 & 0.42 & 5 & 8 & 1.17 & 0.74 & 1.46 & 0.20 & 314 & 38.90 \\
\hline 85 & HUGC10-2T1 & Thua Thien Hue & Clay loam & Groundnut & 1 & 0.33 & 5 & 8 & 1.09 & 0.79 & 1.32 & 0.12 & 516 & 35.37 \\
\hline 86 & HUGC15T1 * & Thua Thien Hue & Clay loam & Groundnut & 1 & 0.43 & 4 & 7 & 0.98 & 0.67 & 1.28 & 0.15 & 752 & 29.98 \\
\hline 87 & HUGC16T2 & Thua Thien Hue & Clay loam & Groundnut & 1 & 0.48 & 4 & 7 & 1.02 & 0.69 & 1.22 & 0.11 & 734 & 22.73 \\
\hline 88 & HUGC17T1 & Thua Thien Hue & Clay loam & Groundnut & 1 & 0.44 & 4 & 8 & 0.99 & 0.69 & 1.26 & 0.13 & 880 & 23.88 \\
\hline 89 & HUGC19T1 * & Thua Thien Hue & Clay loam & Groundnut & 1 & 0.44 & 4 & 7 & 1.02 & 0.85 & 1.20 & 0.10 & 876 & 31.16 \\
\hline 90 & HUGC21T1 & Thua Thien Hue & Clay loam & Groundnut & 1 & 0.37 & 5 & 8 & 1.06 & 0.72 & 1.40 & 0.19 & 830 & 25.59 \\
\hline 91 & HUGC24T1 & Thua Thien Hue & Clay loam & Groundnut & 1 & 0.35 & 5 & 8 & 1.16 & 0.86 & 1.48 & 0.15 & 342 & 34.11 \\
\hline 92 & HUGC26T1 & Thua Thien Hue & Clay loam & Groundnut & 1 & 0.36 & 5 & 8 & 1.06 & 0.76 & 1.38 & 0.16 & 632 & 43.57 \\
\hline 93 & HUGC27T1 & Thua Thien Hue & Clay loam & Groundnut & 1 & 0.40 & 5 & 8 & 1.15 & 0.77 & 1.37 & 0.15 & 516 & 18.22 \\
\hline 94 & HUGC27T2 & Thua Thien Hue & Clay loam & Groundnut & 1 & 0.45 & 5 & 8 & 1.20 & 0.82 & 1.46 & 0.17 & 576 & 39.80 \\
\hline 95 & HUGC29T1 & Thua Thien Hue & Clay loam & Groundnut & 1 & 0.43 & 4 & 7 & 0.88 & 0.74 & 1.17 & 0.10 & 1042 & 38.41 \\
\hline 96 & HUGC30T1 & Thua Thien Hue & Clay loam & Groundnut & 1 & 0.42 & 5 & 8 & 0.95 & 0.70 & 1.15 & 0.10 & 926 & 37.67 \\
\hline 97 & HUGC4T1 & Thua Thien Hue & Clay loam & Groundnut & 1 & 0.47 & 4 & 7 & 0.96 & 0.80 & 1.20 & 0.11 & 1,020 & 31.73 \\
\hline 98 & HUGC7T1 & Thua Thien Hue & Clay loam & Groundnut & 1 & 0.33 & 5 & 8 & 0.97 & 0.63 & 1.31 & 0.20 & 868 & 30.59 \\
\hline 99 & HUGC7T2 & Thua Thien Hue & Clay loam & Groundnut & 1 & 0.41 & 5 & 8 & 0.93 & 0.66 & 1.39 & 0.15 & 724 & 29.21 \\
\hline 100 & HUGC7T3 & Thua Thien Hue & Clay loam & Groundnut & 1 & 0.43 & 5 & 8 & 1.01 & 0.65 & 1.21 & 0.15 & 702 & 43.07 \\
\hline 101 & HUGC9T1 & Thua Thien Hue & Clay loam & Groundnut & 1 & 0.41 & 5 & 8 & 1.12 & 0.78 & 1.53 & 0.15 & 642 & 41.21 \\
\hline 102 & HUMC20T1 $*$ & Thua Thien Hue & Clay loam & Taro & 1 & 0.42 & 5 & 8 & 1.02 & 0.62 & 1.46 & 0.20 & 635 & 37.35 \\
\hline 103 & HUTC1T1 $*$ & Thua Thien Hue & Clay loam & Tomato & 1 & 0.45 & 4 & 7 & 1.23 & 0.88 & 1.60 & 0.19 & 492 & 46.75 \\
\hline
\end{tabular}
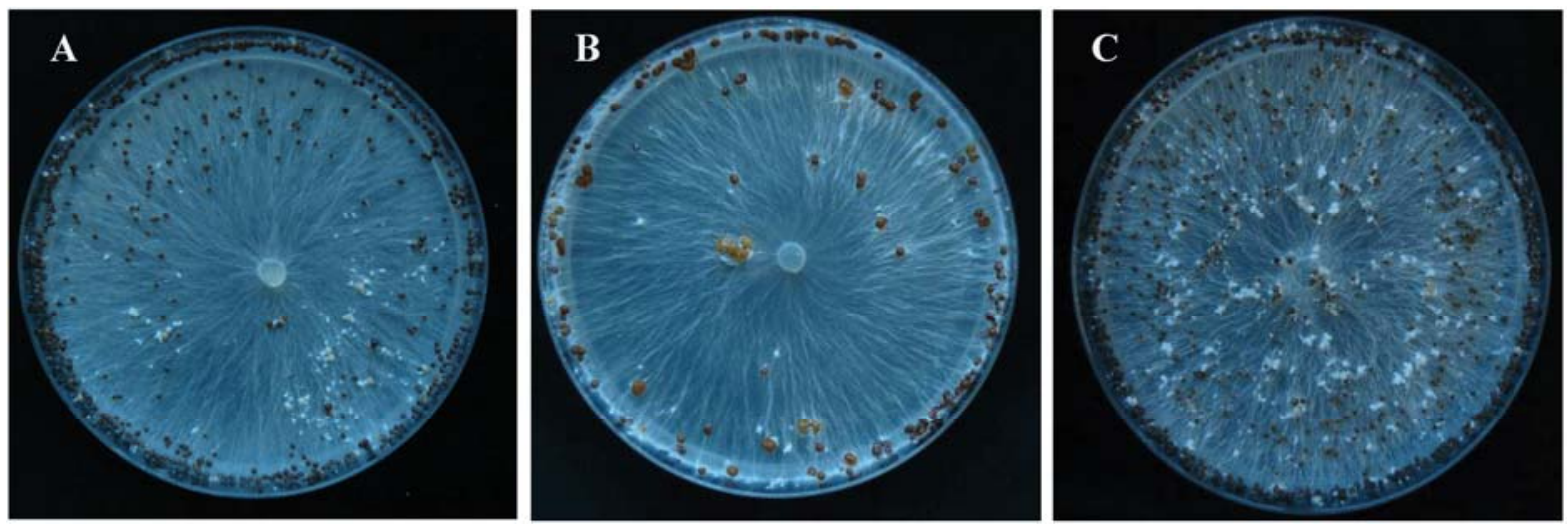

Fig. 5. Phenotypic characteristics of mycelium and sclerotia of three Sclerotium rolfsii isolates belonging to internal transcribed spacer ribosomal DNA groups 1 (A), 2 (B), and 3 (C). A 5-mm-diameter mycelial agar plug was inoculated in the center of a $9-\mathrm{cm}$-diameter potato dextrose agar plate and incubated at $25^{\circ} \mathrm{C}$. All isolates have the typical white-silky mycelium with round or irregular, light- to dark-brown sclerotia.

populations in groundnut fields may help to adopt and develop effective and sustainable control measures. Our field survey in central Vietnam in 2009 showed that the incidence of stem rot disease of groundnut caused by $S$. rolfsii was 5 to $25 \%$. This is similar to that reported in Georgia from 1983 to 1985 (i.e., approximately $8.5 \%$ ) (8) but much higher than the disease incidence reported in Texas in 1992 and 1993 (less than 1\%) (39). On the other hand, it was lower than in Ibaraki (Japan) where disease incidence was 10 to $40 \%$ (25). The observed gradient in stem rot disease incidence across central Vietnam, with an increase in disease incidence from the northern to the southern field sites, might be related to the effect of temperature on disease development (28). Important to note is that the field sites surveyed in the two southern provinces were sites where tomato and taro are also cultivated. Both crops are hosts of $S$. rolfsii and may have contributed to the build-up of pathogen inoculum. For two of the four provinces (i.e., locations B and C), the 
disease incidence of groundnut plants cultivated in clay loam soil was significantly higher than in sandy soil. This difference may be related, in part, to the higher organic content of the clay loam soil, a characteristic that is known to support germination of sclerotia and subsequent hyphal growth toward the host plant (28).

Phylogenetic analysis of the ITS-rDNA sequences revealed three main groups among the 103 isolates from central Vietnam. These results suggest that the $S$. rolfsii population in groundnut fields in central Vietnam is relatively uniform. However, ITS-rDNA sequencing does not give detailed insight into the intraspecific diversity. For $S$. rolfsii, several other techniques and molecular markers have been used to assess intraspecific diversity, especially random amplified polymorphic DNA (RAPD) analysis (32). Multiples of these tests, aimed at characterizing the intraspecific diversity of the isolates, were performed in this study with an initial seven $S$. rolfsii isolates from the collection (i.e., three isolates from Vietnam and four reference strains from culture collections). However, RAPD analysis, as well as repetitive element PCR and enterobacterial repetitive intergenic consensus PCR (22), gave inconsistent or irreproducible results and were not considered useful. Therefore, a range of other traits, including pathogenicity, growth rate, sclerotial characteristics, mycelial compatibility, and tebuconazole sensitivity, were analyzed to get more insight into the intraspecific diversity of the collection of $S$. rolfsii isolates from central Vietnam.

On average, isolates from ITS groups 1, 2, and 3 showed no significant differences in growth rate but exhibited considerable variation in the time to form sclerotia, their maturation time, and their number and size. These results confirm and extend results obtained in previous studies on $S$. rolfsii isolates from other crops and geographic locations $(18,27,29,45)$. For example, the number of sclerotia produced by $S$. rolfsii isolates from chickpea ranged from 150 to 1,210 and their diameter from 0.5 to $2.0 \mathrm{~mm}$ (18). Similar degrees of variation in sclerotial characteristics were found by $\mathrm{Xu}$ et al. (45) for $S$. rolfsii isolates from different hosts and geographic locations. The ITS group 2 isolates from this study produced substantially fewer sclerotia per plate; also, the average maturation time and sclerotial diameter were approximately two times greater than for isolates of ITS groups 1 and 3. These characteristics combined with the light brown color of the sclerotia of the three ITS group 2 isolates were also reported for isolates classified morphologically or by LSU sequencing as $S$. rolfsii var. delphinii $(3,29,45)$.

For several fungi, mycelial compatibility is used to get insight into the genetic relatedness of isolates or to identify intraspecific variation within field populations of plant pathogens (17). When confronted with one another, a demarcation or barrage zone between the fungal colonies places these isolates in different MCGs. Isolates in the same MCG can be clonal (17) or generally exhibit a higher degree of genetic relatedness than isolates from different MCGs $(33,44)$. In a study by Punja and Sun (32) on $S$. rolfsii isolates from 13 countries and 36 different host species, 71 MCGs were found and there was no clear relationship between the original host plant and the MCG, except for $S$. rolfsii isolates from turfgrass. Within each of the three ITS groups identified in our study, a high variation in mycelial compatibility was observed. For isolates of ITS group 1, 91 combinations were tested and only $6.6 \%$ of these combinations showed a compatible interaction, pointing to at least nine MCGs. In contrast, studies by Adandonon et al. (1) on $S$. rolfsii from cowpea fields in Benin revealed four MCGs among a total of 66 isolates. Similarly, Okabe and Matsumoto (25) found four MCGs among a total of 132 isolates from groundnut fields in Ibaraki (Japan) and concluded, based on RAPD analysis, that many isolates were clonal. Based on the MCG analysis, our results suggest that $S$. rolfsii populations from groundnut fields in central Vietnam are more diverse. This may be partly due to the fact that the fields sampled in our study are far apart (i.e., approximately $400 \mathrm{~km}$ from the northern fields sites to the southern field sites compared with only $2.5 \mathrm{~km}$ in the study by Okabe and Matsumoto; 25). It should be emphasized, however, that mycelial compatibility refers to macroscopic observations in which hyphae of different isolates readily intermingle without forming a barrage or inhibition zone. Therefore, the MCGs found here cannot automatically be considered as vegetative compatibility groups or anastomosis groups, because anastomosis and heterokaryon formation was not confirmed microscopically.

The results further showed small variations in tebuconazole sensitivity of $S$. rolfsii isolates from groundnut fields in central Vietnam. This is substantially less than reported earlier by Franke et al. (14) for the $S$. rolfsii population from Georgia. The three isolates from ITS group 2, collected from the remote upland region, were significantly more sensitive to tebuconazole than those from ITS group 1. Although this may be due, in part, to a sample size difference, it may also be linked to the fact that farmers in this remote area do not use tebuconazole. In the other farmer fields surveyed, however, no records are kept on fungicide use; therefore, for the fields included in this study, no correlation can be established between sensitivity and fungicide use. Franke et al. (14) found a correlation between reduced sensitivity to tebuconazole among isolates from fields with a history of repeated applications of this fungicide. In Vietnam, tebuconazole is used to control $S$. rolfsii but not on a regular basis or a large scale due to its relatively high costs for subsistence farmers.

In conclusion, the work presented here is the first study on the distribution, incidence, and diversity of $S$. rolfsii populations in groundnut fields in central Vietnam. $S$. rolfsii isolates originating from groundnut, tomato, and taro were all pathogenic on groundnut and displayed substantial diversity of various genetic and phenotypic traits, including mycelial compatibility, growth rate, and sclerotial characteristics. The observation that the $S$. rolfsii isolates tested were all relatively sensitive to tebuconazole provides opportunities to use this fungicide to control stem rot disease of groundnut in central Vietnam. Combination with other control measures, including biological control, is recommended to prevent resistance development, as was observed previously for other $S$. rolfsii populations exposed repeatedly to this fungicide.

Table 6. Sensitivity to tebuconazole of Sclerotium rolfsii isolates from groundnut fields in central Vietnam ${ }^{\mathrm{a}}$

\begin{tabular}{lc}
\hline ITS $^{\mathbf{b}}$ & Growth inhibition $(\boldsymbol{\%})(\mathbf{m e a n} \pm \mathbf{S D})^{\mathbf{c}}$ \\
\hline 1 & $35.5 \pm 8.7$ \\
2 & $45.9 \pm 3.1$ \\
3 & $42.7 \pm 11.6$ \\
\hline
\end{tabular}

a The mean inhibition of radial mycelial growth was determined at the tebuconazole concentration of $0.02 \mathrm{mg} \mathrm{liter}^{-1}$ of potato dextrose agar. The relative inhibition of mycelial growth was calculated based on the formula inhibition $(\%)=100-[$ (colony diameter on amended medium/ colony diameter on control) $\times 100 \%]$.

${ }^{\mathrm{b}}$ Internal transcribed spacer (ITS) group.

${ }^{\mathrm{c}} \mathrm{SD}=$ standard deviation.

Table 5. Mycelial compatibility between Sclerotium rolfsii isolates for each of the three identified internal transcribed spacer (ITS) groups

\begin{tabular}{|c|c|c|c|c|c|}
\hline ITS group & Number of isolates & Number of combinations & Compatible combinations & Compatibility (\%) & Number of MCGs $\mathbf{s}^{\mathrm{a}}$ \\
\hline 1 & 14 & 91 & 6 & 6.6 & 9 \\
\hline 2 & 3 & 3 & 1 & 33.3 & 2 \\
\hline 3 & 9 & 36 & 4 & 11.1 & 6 \\
\hline
\end{tabular}

a Mycelial compatibility groups. 


\section{Acknowledgments}

We thank L. T. N. Thuy and L. T. L. Giang for their help during the field studies in Vietnam, all of the farmers who made their fields available for this survey, and F. Govers for critically reading this manuscript and valuable suggestions.

\section{Literature Cited}

1. Adandonon, A., Aveling, T. A. S., van der Merwe, N. A., and Sanders, G. 2005. Genetic variation among Sclerotium isolates from Benin and South Africa, determined using mycelial compatibility and ITS rDNA sequence data. Australas. Plant Pathol. 34:19-25.

2. Akram, A., Iqbal, S. H. M., Qureshi, R. A., and Rauf, C. A. 2008. Variability among isolates of Sclerotium rolfsii associated with collar rot disease of chickpea in Pakistan. Pak. J. Bot. 40:453-460.

3. Aycock, R. 1966. Stem Rot and Other Diseases Caused by Sclerotium rolfsii or the Status of Rolfs' Fungus after 70 years. North Carolina State University, Raleigh.

4. Besler, B. A., Grichar, W. J., Starr, J. A., Senseman, S. A., Lemon, R. G., and Jaks, A. J. 2006. Effects of peanut row pattern, cultivar, and fungicides on control of Southern stem rot, early leaf spot, and rust. Peanut Sci. 33:1-6.

5. Branch, W. D., and Brenneman, T. B. 1996. Pod yield and stem rot evaluation of peanut cultivars treated with tebuconazole. Agron. J. 88:933-936.

6. Branch, W. D., and Brenneman, T. B. 1999. Stem rot disease evaluation of mass-selected peanut populations. Crop Prot. 18:127-130.

7. Branch, W. D., and Brenneman, T. B. 2009. Field evaluation for the combination of white mould and tomato spotted wilt disease resistance among peanut genotypes. Crop Prot. 28:595-598.

8. Branch, W. D., and Csinos, A. S. 1987. Evaluation of peanut cultivars for resistance to field infection by Sclerotium rolfsii. Plant Dis. 71:268-270.

9. Brenneman, T. B., and Murphy, A. P. 1991. Activity of tebuconazole on Cercosporidium personatum, a foliar pathogen of peanut. Plant Dis. 75:699703.

10. Brewster, V. 2001. Southern blight, Southern stem blight, White mold. APSnet. Online publication.

11. Brown, S. L. 2009. Peanut insects: ecology and control. Pages 1-10 in: Encyclopedia of Pest Management, Taylor \& Francis, London.

12. Cating, R. A., Palmateer, A. J., and McMillan, J. R. T. 2009. First report of Sclerotium rolfsii on Ascocentrum and Ascocenda orchids in Florida. Plant Dis. 93:963.

13. FAO. 2010. FAO Statistics Division. Online publication.

14. Franke, M. D., Brenneman, T. B., Stevenson, K. L., and Padgett, G. B. 1998. Sensitivity of isolates of Sclerotium rolfsii from peanut in Georgia to selected fungicides. Plant Dis. 82:578-583.

15. Hammons, R. O. 1994. The origin and history of the groundnut. Pages 2442 in: The Groundnut Crop: A Scientific Basis for Improvement. J. Smartt, ed. Chapman \& Hall, London.

16. Harlton, C. E., Levesque, C. A., and Punja, Z. K.. 1995. Genetic diversity in Sclerotium (Athelia) rolfsii and related species. Phytopathology 85:12691281.

17. Kohn, L. M., Stasovski, E., Carbone, I., Royer, J., and Anderson, J. B. 1991. Mycelial incompatibility and molecular markers identify genetic variability in field populations of Sclerotinia sclerotiorum. Phytopathology 81:480485.

18. Kokub, D., Azam, F., Hassan, A., Ansar, M., Asad, M. J., and Khanumand, A. 2007. Comparative growth, morphological and molecular characterization of indigenous Sclerotium rolfsii strains isolated from different locations of Pakistan. Pak. J. Bot. 39:1849-1866.

19. Lakpale, N., Khare, N., and Thrimurty, V. S. 2007. Suppression of Sclerotium rolfsii Sacc.: an intergrated approach. Soils Crops 17:241-245.

20. Le, C. N. 2004. Study wilt diseases on groundnut and some methods to control them in Thua Thien Hue province. Natl. J. Plant Prot. 1:9-15.

21. Matheny, P. B., Curtis, J. M., Hofstetter, V., Aime, M. C., Moncalvo, J. M., Ge, Z. W., Yang, Z. L., Slot, J. C., Ammirati, J. F., Baroni, T. J., Bougher, N. L., Hughes, K. W., Lodge, D. J., Kerrigan, R. W., Seidl, M. T., Aanen, D. K., DeNitis, M., Daniele, G. M., Desjardin, D. E., Kropp, B. R., Norvell, L. L., Parker, A., Vellinga, E. C., Vilgalys, R., and Hibbett, D. S. 2006. Major clades of Agaricales: A multilocus phylogenetic overview. Mycologia
98:982-995.

22. McDonald, J. G., Wong, E., and White, G. P. 2000. Differentiation of Tilletia species by rep-PCR genomic fingerprinting. Plant Dis. 84:1121-1125.

23. Nguyen, T. N., Tran, V. M., Nguyen, T. T., and Le, C. N. 2004. Research on groundnut diseases in Quang Binh province. Natl. Agric. Rural Dev. 17:337-342.

24. Okabe, I., Arakawa, M., and Matsumoto, N. 2001. ITS polymorphism within a single strain of Sclerotium rolfsii. Mycoscience 42:107-113.

25. Okabe, I., and Matsumoto, N. 2000. Population structure of Sclerotium rolfsii in peanut fields. Mycoscience 41:145-148.

26. Okabe, I., and Matsumoto, N. 2003. Phylogenetic relationship of Sclerotium rolfsii (teleomorph Athelia rolfsii) and $S$. delphinii based on ITS sequences. Mycol. Res. 107:164-168.

27. Prasad, R. D., and Naik, M. K. 2008. Advances in plant diseases caused by Sclerotium rolfsii and their management. Pages 89-127 in: Advances in Soil Borne Plant Diseases. Naik and D. Rani, eds. New India Publishing Agency, New Delhi, India.

28. Punja, Z. K. 1985. The biology, ecology, and control of Sclerotium rolfsii. Annu. Rev. Phytopathol. 23:97-127.

29. Punja, Z. K., and Damiani, A. 1996. Comparative growth, morphology, and physiology of three Sclerotium species. Mycologia 88:694-706.

30. Punja, Z. K., and Grogan, R. G. 1983. Hyphal interactions and antagonism among field isolates and single-basidiospore strains of Athelia (Sclerotium) rolfsii. Phytopathology 73:1279-1284.

31. Punja, Z. K., and Rahe, J. E. 1993. Sclerotium. In: L. L. Singleton, J. D. Mihail, and C. M. Rush, eds. Methods for Research on Soilborne Phytopathologenic Fungi. The American Phytopathological Society, St. Paul, MN

32. Punja, Z. K., and Sun, L. J. 2001. Genetic diversity among mycelia compatibility groups of Sclerotium rolfsii (teleomorph Athelia rolfsii) and $S$. delphinii. Mycol. Res. 105:537-546.

33. Rayner, A. D. M. 1991. The challenge of the individualistic mycelium. Mycologia 83:48-71.

34. Remesal, E., Lucena, C., Azpilicueta, A., Landa, B. B., and Navas-Cortes, J. A. 2010. First report of Southern blight of pepper caused by Sclerotium rolfsii in Southern Spain. Plant Dis. 94:280-280.

35. Ristaino, J. B., Johnson, A., Blanco-Meneses, M., and Liu, B. 2007. Identification of the tobacco blue mold pathogen, Peronospora tabacina, by polymerase chain reaction. Plant Dis. 91:685-691.

36. Savage, G. P., and Keenan, J. I. 1994. The composition and nutritive value of groundnut kernels. Pages 173-213 in: The Groundnut Crop: A Scientific Basis for Improvement. J. Smartt, ed. Chapman \& Hall, London.

37. Scinos, A. S. 1989. Targeting fungicides for control of Southern stem rot on peanut. Plant Dis. 73:723-726.

38. Shew, B. B., and Waliyar, F. 2005. Peanut diseases: ecology and control Page 1450 in: Encyclopedia of Pest Management, Vol. 33. Taylor \& Francis, London.

39. Shim, M. Y., Starr, J. L., Keller, N. P., Woodard, K. E., and Lee, T. A. 1998. Distribution of isolates of Sclerotium rolfsii tolerant to pentachloronitrobenzene in Texas peanut fields. Plant Dis. 82:103-106.

40. Tendulkar, S. R., Gupta, A., and Chattoo, B. B. 2003. A simple protocol for isolation of fungal DNA. Biotechnol. Lett. 25:1941-1944.

41. Wadsworth, D. F., and Melouk, H. A. 1984. Tolerance of Sclerotium rolfsii to pentachloronitrobenzene. Phytopathology 74:634-634.

42. White, T. J., Bruns, T., Lee, S., and Taylor, J. 1990. Amplification and direct sequencing of fungal ribosomal RNA genes for phylogenetics. In: PCR Protocols: A Guide to Methods and Applications. M. A. Innis, D. H. Gelfand, J. J. Sminsky, and T. J. White, eds. Academic Press, Inc., New York.

43. Woodward, J. E., Brenneman, T. B., Kemerait, R. C., Smith, N. B., Culbreath, A. K., and Stevenson, K. L. 2008. Use of resistant cultivars and reduced fungicide programs to manage peanut diseases in irrigated and nonirrigated fields. Plant Dis. 92:896-902.

44. Worrall, J. J. 1997. Somatic incompatibility in basidiomycetes. Mycologia 89:24-36.

45. Xu, Z. H., Harrington, T. C., Gleason, M. L., and Batzer, J. C. 2010 Phylogenetic placement of plant pathogenic Sclerotium species among teleomorph genera. Mycologia 102:337-346. 